\title{
Therapeutic application of $T$ regulatory cells in composite tissue allotransplantation
}

\author{
Jeong-Hee Yang and Seok-Chan Eun * (1)
}

\begin{abstract}
With growing number of cases in recent years, composite tissue allotransplantation (CTA) has been improving the quality of life of patient who seeks reconstruction and repair of damaged tissues. Composite tissue allografts are heterogeneous. They are composed of a variety of tissue types, including skin, muscle, vessel, bone, bone marrow, lymph nodes, nerve, and tendon. As a primary target of CTA, skin has high antigenicity with a rich repertoire of resident cells that play pivotal roles in immune surveillance. In this regard, understanding the molecular mechanisms involved in immune rejection in the skin would be essential to achieve successful CTA. Although scientific evidence has proved the necessity of immunosuppressive drugs to prevent rejection of allotransplanted tissues, there remains a lingering dilemma due to the lack of specificity of targeted immunosuppression and risks of side effects. A cumulative body of evidence has demonstrated T regulatory (Treg) cells have critical roles in induction of immune tolerance and immune homeostasis in preclinical and clinical studies. Presently, controlling immune susceptible characteristics of CTA with adoptive transfer of Treg cells is being considered promising and it has drawn great interests. This updated review will focus on a dominant form of Treg cells expressing $\mathrm{CD} 4^{+} \mathrm{CD} 25^{+}$surface molecules and a forkhead box P3 transcription factor with immune tolerant and immune homeostasis activities. For future application of Treg cells as therapeutics in CTA, molecular and cellular characteristics of CTA and immune rejection, Treg cell development and phenotypes, Treg cell plasticity and stability, immune tolerant functions of Treg cells in CTA in preclinical studies, and protocols for therapeutic application of Treg cells in clinical settings are addressed in this review. Collectively, Treg cell therapy in CTA seems feasible with promising perspectives. However, the extreme high immunogenicity of CTA warrants caution.
\end{abstract}

Keywords: Composite tissue allotransplantation, Immune rejection, Skin antigenicity, T regulatory cell, Immune tolerance, Immunosuppressive drug, Cell therapy

\section{Background}

Since the first successful human hand transplantation performed in 1998 [1] and human face transplantation performed in 2005 [2], composite tissue allotransplantation (CTA) for reconstruction of damaged or defected tissues has been rapidly emerging in the last two decades. Up to date, over 100 cases of hand transplantation and more than 30 cases of partial or full facial transplantation have been conducted worldwide [3, 4]. Advancements in CTA have been improving the quality of life

\footnotetext{
*Correspondence: sceun@snubh.org

Department of Plastic and Reconstructive Surgery, Composite Tissue

Allotransplantation Immunology Laboratory, Seoul National University

College of Medicine, Seoul National University Bundang Hospital,

Seongnam, South Korea
}

of patient who has damaged tissues such as massive burns, cancer resections, congenital malformations, and accident-related traumas. Composite tissue allografts are heterogeneous. They are composed of various tissue types, including skin, muscle, vessel, bone, bone marrow, lymph nodes, nerve, tendon, and different transplanted elements with different immunogenic characteristics [57]. Skin, the primary target of CTA, has a rich repertoire of resident cells that play pivotal roles in immune surveillance. In this regard, understanding the molecular mechanism involved in immune rejection in the skin would be essential to successful CTA. Although there is scientific evidence demonstrating that the necessity of immunosuppressive drugs to prevent rejection of the transplanted tissues, $85-90 \%$ of hand transplant patients have experienced at least one episode of acute skin rejection with 
conventional immunosuppressive protocol, contrasts to the rejection rate of less than $10 \%$ in organ transplantation $[8,9]$. There is a lingering dilemma in CTA because of limited responsiveness due to the lack of specificity and efficacy of targeted immunosuppressive drugs, which also have side effects such as risks of infection, cancer development, metabolic toxicity, and hypertension [10]. Maintaining immunosuppressive drugs on CTA would be challenging. Thus, there have been efforts to develop Treg cells with donor antigen-specificity to avoid harm to the body's immune system.

Treg cells expressing $\mathrm{CD} 4^{+} \mathrm{CD} 25^{+} \mathrm{Foxp} 3^{+}$are a dominant form of $\mathrm{T}$ regulatory cell. The immune tolerant role of naturally arising Treg cells in autoimmune diseases and their effects on prolonged allograft survival in CTA with transplant rejection prevention function have been well documented in preclinical model studies [11, 12]. Moreover, several studies have demonstrated that Treg cells participate in allotransplantation tolerance across major histocompatibility complex (MHC) barriers, thus, broadening the applicability of Treg cells in CTA [13, 14]. Mechanisms involved in the immune tolerant function of Treg cells targeting inhibition of $\mathrm{T}$ effector (Teff) cells can be described as follows: (1) suppression of dendritic cells (DCs) maturation and production of indoleamine 2,3-dioxygense; (2) production of granzyme A/B and perforin that leads to lysis of Teff cells; (3) deprivation of IL-2 via high affinity CD25 (IL-2R $\alpha)$; (4) release of inhibitory cytokines such as TGF- $\beta$, IL-10, and IL-35; (5) production of cAMP metabolites with disruption of metabolomics in Teff cells [15]. In addition, immune regulatory modalities of Treg cells combined with immunosuppressive drugs have offered options of Treg cell therapy in CTA [16].

In this updated review on therapeutic application of Treg cells in CTA, molecular and cellular characteristics of CTA and immune rejection, Treg cell development and phenotypes, Treg cell plasticity and stability, immune tolerant functions of Treg cells in CTA in preclinical studies, and protocols for therapeutic application of Treg cells in clinical settings are addressed. Collectively, Treg cell therapy in CTA seems feasible with promising perspectives. Managing skin antigenicity would be essential to achieve successful CTA and allotransplantation in general.

\section{Characteristics of CTA and immune rejection}

High rate of acute graft rejection is one main characteristic of CTA which is composed of diverse layers of tissues [7]. In particular, the antigenicity of skin has been amply demonstrated by multiple rejection episodes in clinical hand transplant patients [17]. It has been reported a rich repertoire of skin-resident immune cells play pivotal roles in immune surveillance $[18,19]$. Examination of early human skin allograft has shown that endothelial cells of microvasculature are the critical targets of $\mathrm{CD}_{4}^{+}$and $\mathrm{CD}^{+} \mathrm{T}$ lymphocytes of recipients in first-set vascularized skin allograft rejection, resulting in extensive microvascular damage [20,21]. By contrast, in facial allografts, analysis of acute rejection has shown that donor lymphocytes are major sources of immune rejection in the rejected area [22]. In addition, abundant skin-resident $\mathrm{T}$ cells of donor origin are found to be associated with vascular, pilosebaceous, and epidermal sites of injury [22]. Considering that skin is the primary target of immune rejection in CTA, it seems reasonable to pay attention to the skin resident cells participating in immune surveillance due to multiple episodes of skin allografts rejection. Skin explants rejection studies have revealed that Langerhans cells with expression of unregulated MHC class II antigens are migrated out of the skin, and their maturation proceeded by local inflammatory cytokines eventually leads to rejection [23]. Microscopic observation of skin allografts has revealed that the dermis appears to be spared while the epithelium is destroyed in transplantation rejection [24]. These results indicate that elucidating molecular and cellular characteristics of skin and resident cells might help us understand the episodes of skin allograft rejection. A variety of immune cells such as Langerhans cells, dermal DCs, macrophages, mast cells, and diverse $\mathrm{T}$ cell receptor (TCR) repertoire of $\mathrm{T}$ cells [ $\mathrm{T}$ effector memory $\left(\mathrm{T}_{\mathrm{EM}}\right)$ cells of CD4 and CD8, Treg cells, and tissue resident memory $T$ cells $\left.\left(\mathrm{T}_{\mathrm{RM}}\right)\right]$ are located in normal skin [25]. It has been estimated that $98 \%$ of cutaneous lymphocyte antigen (CLA) $\mathrm{T}_{\mathrm{EM}}$ cells reside in the normal skin [26]. These cells can cause rapid and sensitive immune reactions in allografts with expression of CD69, CD103, and CLA. A large pool of memory T cells in the skin can be distinguished from memory $\mathrm{T}$ cells in the blood by differential pattern of gene expression. They can mediate immune reactions without recruiting $\mathrm{T}$ cells from the blood [27]. Signs of rejection in CTA patients with administration of immunosuppressive drug are sharply contrasted to those of kidney transplantation patients whose immune rejection is fairly controlled [10, 19, 20, 28]. Interestingly, split tolerance and hierarchy of antigenicity as characteristics of CTA have been observed in animal studies. A MHC-I mismatched tolerant kidney of swine model has demonstrated that CTA is accepted for a long time with the exception of the epidermis [29]. Exposure of tolerant animals to second donor-matched kidneys prior to CTA has increased the longevity of CTA epidermis [29]. In a limb allograft model, individual tissue graft of the muscle or skin has shown greater 
cellular and humoral immune rejection rates than total limb grafts [30]. These results highlight the importance of immune modulation of skin antigenicity for successful CTA.

The development of modern immunosuppressive drugs has prevented rejection of allografts. It had opened a new era of CTA [7]. Following the first successful human kidney transplantation between twin brothers in 1954 [31], azathioprine and prednisolone have been introduced to renal transplantation. Polyclonal anti-thymocyte globulin (ATG) preparations became available in the 1970s [32]. In the 1980s, cyclosporine became the first single drug that could control graft rejection [33]. Trials that demonstrate the benefit of cyclosporine in kidney recipients compared to azathioprine and steroids have assured the use of cyclosporine in solid-organ transplantation [33]. Subsequently, a combination of immunosuppressive regimen given at the time of transplantation (induction therapy) and during maintenance phase is used conventionally in CTA [34]. Although immunosuppressive drugs can almost completely prevent acute rejection rooted in the induction of immune tolerance during transplantation, chronic rejection of organ allografts still remains a problem. In addition, the use of non-specific immunosuppressive drugs has various side effects, including the development of multiple malignancies [10]. In general, patients with CTA face rather tough decision over organ transplantation when the issue is aesthetic than life-threatening.

The concept of induced tolerance to allografts arose from the pioneering work of Nobel laureate Sir Peter Medawar and colleagues. They have suggested that acquired tolerance is due to specific failure of the host's immunological response and that the antigenic properties of homografts (allografts) are not altered by residence in a tolerant host as the host itself retains the power of passively acquired immunity directed against a homograft (allograft) [35]. In terms of the concept of induction of tolerance to the host to prevent allograft rejection, Treg cells are likely to fit such concept. It has been found that CTA is well accepted up to 6 years after transplantation in the presence of Treg cells with expression of immune suppressive cytokines, such as interleukin-10 (IL-10) or transforming growth factor- $\beta$ (TGF- $\beta$ ) [36]. The involvement of Treg cells in inhibition of transplant arteriosclerosis combined with rapamycin treatment known to expand Treg cells suggests that adoptive transfer of Treg cells in induction of immune tolerance in CTA is feasible [37]. Thus, preventing immune responses to foreign cells and tissues by Treg cells may offer a new way to minimize reliance on non-specific immunosuppressive drug. This could ultimately allow patients to be completely withdrawn from drug-based immunosuppression.

\section{Treg cell development and phenotypes}

Treg cells are associated with a variety of immune related reactions, including autoimmune disease, transplantation, allergy, infection, and cancer. A dominant form of the subset is $\mathrm{CD} 4{ }^{+} \mathrm{CD} 25^{+}$Foxp $3^{+}$Teg cells. Transcription factor Foxp3 is known as a mast regulator central to the development of Treg cells [38, 39]. Mutations in Foxp3 gene is directly linked to severe multi-organ autoimmune diseases, including immune dysregulation polyendocrinopathy enteropathy X-linked syndrome (IPEX) in human and scurfy mice [40, 41]. To simplify the nomenclature, Treg cells are classified into three types: thymic Treg (tTreg) cells induced in the thymus, peripherally induced Treg (pTreg) cells, and in vitro induced Treg (iTreg) cells [42]. In the thymus, tTreg cells are developed from bone marrow derived precursor cells in the cortex and medullary region via the following two steps. The first step involves the development of a Foxp $3^{-}$CD25 $5^{\text {hi }} \mathrm{T}$ cell intermediate in TCR dependent manner. The second step involves the development of Foxp $3^{\text {hi }} \mathrm{T}$ cells under the influence of IL-2 independent of TCR [43-45]. Most self-antigen reactive T cells are deleted centrally during $\mathrm{T}$ cell development while tTreg cells are exported to the periphery to maintain immune tolerance and immune homeostasis. Although signals for the generation and function of pTreg cells are less clear, pTreg cells are induced in the periphery by antigen presentation in non-immunogenic, inflammatory, and noninflammatory conditions [46, 47]. In mice subjected to neonatal thymectomy, analyses of adoptive $\mathrm{T}$ cell transfer into lymphopenic hosts have led to the identification of a specialized subset of pTreg cells capable of suppressing autoimmunity and immune suppressive function under inflammation. Especially, pTreg cells function in immune tolerance is well manifested at the mucosal site $[48,49]$.

During development, a population of FoxP3 ${ }^{-} \mathrm{CD}_{2} 5^{\text {hi }}$ $\mathrm{T}$ cell intermediates derived from thymic precursor $\mathrm{T}$ cells is precommitted to differentiate into Foxp $3^{+}$Treg cells upon TCR stimulation $[50,51]$. On this line, periphery $\mathrm{T}$ cells termed recent thymic emigrants (RTE) are observed to be exclusive precursor cells of pTregs. They can be developed into Foxp $3^{\text {bright }} \mathrm{CD} 25^{\text {high }}$ Treg cell phenotypes in the human and mice [52]. Interestingly, a study has shown that pTreg cells can recirculate to the thymus and suppress the development of their precursors [53]. This indicates that development of tTreg and pTreg cells is tightly co-regulated and balanced. Interestingly, tTreg cell population renders naïve $\mathrm{T}$ cells to be tolerant, thus, creating 'infectious tolerance' by generating pTreg cells through delivery of TGF- $\beta$ expressed on tTreg cells in transplantation [54, 55]. For the generation of iTreg cells, in vitro animal model studies have found that mice naive $\mathrm{CD} 4{ }^{+} \mathrm{CD} 25^{-} \mathrm{T}$ cells can be induced to express 
CD25 $5^{+} \mathrm{Foxp}^{+}$in presence of IL-2 and TGF- $\beta[56,57]$. Based on such observation in mice, initially, it has been assumed that the generation of human iTregs could be recapitulated under the condition used for mice. Unexpectedly, human iTreg cells expressing Foxp3 in presence of TGF- $\beta$ failed to suppress proliferation of responder $\mathrm{CD}^{+}{ }^{+}$Foxp3 $^{-} \mathrm{T}$ cells [58]. When re-stimulated with PMA or ionomycin, majority of Foxp $3^{+}$iTreg cells produced IL-2 and/or IFN- $\gamma$ [58]. These results suggest that induction of iTreg cells in mice and human system does not seem to be the same. However, another group has successfully induced immunosuppressive human iTreg cells from peripheral blood mononuclear cells (PBMCs) in healthy adults by using retinoic acid (RA), IL-2 and TGF- $\beta$ [59]. Moreover, a recent study has demonstrated that induction of highly suppressive iTreg cells from human umbilical cord blood treated with TGF- $\beta$ and alltrans RA is mediated by the expression of micro RNAs (miRNAs) which can selectively repress genes related to Th17 differentiation [60]. Thus, in vitro expansion of Treg cells to induce immune tolerance therapeutically seems highly promising.

In lineage commitment of Treg cells, an important distinction between tTreg cells and extrathymic Treg cells is that a strong TCR signaling with CD28 co-stimulation just below the threshold for negative selection is necessary for tTreg cells. Extrathymic conversion of naive $\mathrm{T}$ cells into Tregs is inhibited by CD28 costimulation, although such costimulation is critical for survival of pTreg cells which favor weak TCR stimulation [61]. Peptide-MHC ligand potency, density, and duration of TCR interactions are factors that might induce pTreg cells [62]. Under TCR signaling, it has been found that nuclear factor-kappa B (NF-kB) pathway leading to c-Rel is correlated with the expression of Foxp3 as a defect in connecting TCR to NF-kB that curtails Treg cells differentiation [63], indicating that the TCR-NF-kB-c-Rel axis is the main pathway for Foxp $3^{+}$Treg cell development. In addition, nuclear factor of activated T cell (NFAT)-Foxp3 complex can mediate expression of CTLA-4 and CD25, markers for Treg cells [64]. It is notable that the activity of Foxo-1 transcription factor needs to be repressed by Akt kinase during TCR stimulation [65].

Phenotypic standard markers of Treg cells are still controversial. However, upregulated expression of Helios and Nrp-1 in tTreg cells [47] and expression of Helios with high proportion of IL-10, Ebi31, and CTLA-4 in tTreg cells suggest that tTreg cells are distinguishable from pTreg cells [66]. These results are challenged by the observation that there are no differences in expression levels of Helios and Nrp-1 between tTregs and pTreg cells in both mice and human systems $[67,68]$. In the human system, identification of phenotypic Treg cell marker is more difficult because of its heterogeneity and stability. Not surprisingly, functional heterogeneity within human FOXP $^{+}$Treg cells has been observed in single cell analysis [69]. In that study, most human primary Foxp3 ${ }^{+}$ clones have potent suppressive abilities while around $25-30 \%$ of Foxp $3^{+}$clones are lack of suppressive capacity against conventional T (Tconv) responders. Among population of Helios ${ }^{+} \mathrm{Foxp}^{+}{ }^{+}$Treg cells enriched for suppressive clones, Helios ${ }^{-}$Foxp $3^{+}$Treg subpopulation is found to harbor nonsuppressive clones with production of proinflammatory cytokines such as IFN-r, IL-2, and IL-17 [70]. This implies that Helios might be a solid phenotypic marker for Treg cells. GITR, CD39, TNFR2, HLADR, CTLA4, GARP, and LAP are expressed in human Treg cells [71]. They could be considered as presumptive phenotypic markers. However, these molecules are also expressed on activated Tconv cells under inflammatory condition [72]. Nevertheless, CD $4{ }^{+} \mathrm{CD} 25^{+}$Foxp $3^{+}$Treg cells are the best known and the most dominant subset of Treg cells participating in immune tolerance reaction and immune homeostasis so far. Other types of $\mathrm{T}$ cells with regulatory activity but not expressing Foxp3 include type 1 regulatory cells $\left(\mathrm{Tr} 1\right.$ cells), $\mathrm{CD} 4^{+} \mathrm{CD} 25^{+} \mathrm{LAG}^{+} \mathrm{T}$ cell, $\mathrm{Th} 3$, iTr35, $\mathrm{CD}^{+} \mathrm{T}, \mathrm{CD}^{-}{ }^{-} \mathrm{CD} 8^{-}$double negative $\mathrm{T}$ cells, NK $\mathrm{T}$ cells, and $\gamma \delta \mathrm{T}$ cells [73, 74]. A range of cytokine expression and chemokine receptors that can promote differential tissue localization have been observed in these cells. Particularly, immune tolerant activities of $\operatorname{Tr} 1$ cells that can secret IL-10 have drawn a lot interest in future clinical application [75]. In summary, identification of reliable phenotypic markers for Treg cells may pave a way for therapeutic application.

\section{Treg cell plasticity and stability}

The application of immunosuppressive Treg cells for protection against allograft rejection remains rather elusive due to the lack of specific markers. Although Foxp3 is considered as gold standard for Treg cells and extremely resilient with the same immunosuppressive function in mice $[45,76]$, it is notable that human Treg cells are unstable under various inflammatory conditions [72]. In addition, several studies have confirmed that Tconv cells under inflammatory condition express Foxp3 as well [58, $71,77]$. In this regard, our endeavors for application of bona fide Treg cells in CTA seem rather promiscuous due to their plasticity and lack of stability. Studies have shown that Treg cells can lose immune tolerant functions by diverse mechanisms, including co-stimulatory pathways, degradation of Foxp3, epigenetic regulation, and cytokine interaction [78, 79]. It is currently unclear whether any single pathway can regulate Treg cells exclusively. It is assumed that co-stimulatory pathways might differentially regulate Treg and Tconv cells. Despite 
shared TCR sequences between Treg and Tconv cells, the lineage of Treg cells with particular balance and intensity of TCR signals are different from Tconv cells $[44,80]$. In support of unique TCR signaling in Treg cells, nonoverlapping unique CDR3 sequences between tTreg and Tconv cells have been elucidated by sequencing analysis [47]. In vitro expanded mice iTreg cells with combined treatment with anti-CD3, anti-CD28, and IL-2 have wellmaintained functional activities [81]. However, it has been found that but human Treg cells repeatedly stimulated in vitro with anti-CD3 and anti-CD28 antibodies will lose Foxp3 expression, resulting in the generation of pathogenic memory $\mathrm{T}$ cells $[82,83]$. The stability of Treg cells can also be lost by ubiquitination of Foxp3, leading to degradation Foxp3 via signal transducer and activator of transcription 3 (STAT3) signaling. In a STAT5 limited environment, the mTOR/AKT/PI3K pathway and PDL-1can inhibit Foxp3 expression whereas Foxo1 and Wnt signaling can enhance Foxp3 expression, thus inducing immune suppressive function of Treg cells [78, 84]. Epigenetic regulation is another contributing factor to the stability of Treg cells. Epigenetic hypomethylation in Treg-specific demethylated region (TSDR) is crucial to maintaining high Foxp3 expression. Methylation at this site has been reported to be different between Treg cells and $\mathrm{CD} 4^{+}$Tconv cells [85]. Likewise, Treg cells generated in vivo are more strongly demethylated in the Foxp3 locus. They are able to maintain their stability compared to Treg cells generated in vitro [86]. On this line, increased $\mathrm{CPG}$ methylation in a conserved region of the Foxp3 gene in $\mathrm{CD} 4^{+} \mathrm{CD} 25^{+} \mathrm{CD} 127^{\text {low }}$ Treg cells is found to be correlated with the loss of Foxp3 expression and increased production of pro-inflammatory cytokines [82]. Concerning the convertibility of Treg cells, expression of surface markers such as CD45RA or CD127 might be able to define the fate of Treg cells. In a recent study on patients with kidney transplantation tolerance, hypomethylation has occurred on Foxp3 TSDR in CD45RA ${ }^{-}$Foxp $3^{\text {hi }}$ memory Treg cells [87], suggesting that population of CD45RA ${ }^{-}$Foxp $3^{\text {hi }}$ memory Treg cells might produce favorable outcomes in CTA. However, caution is needed as Foxp3 expression does not always guarantee suppressive function of Treg cells. For example, when naive human $\mathrm{CD} 4{ }^{+} \mathrm{CD} 25^{-} \mathrm{CD} 127^{+} \mathrm{CD} 45 \mathrm{RA}{ }^{+}$ $\mathrm{T}$ cells from PBMCs are induced to express high levels of Foxp3 in the presence of IL- 2 and TGF- $\beta$, the production of IFN- $\gamma$ and IL-2 inflammatory cytokines has failed to exert immunosuppressive Treg cells although Foxp3 expression in these cells is stable [58]. Moreover, variations and inconsistent Foxp3 expression have been observed in $\mathrm{T}$ cells expressing high levels of CD25 even in healthy individuals in addition to high levels of CD25 expression in Tconv cells under inflammatory condition. Thus, plasticity and stability of human Treg cells should be considered with great importance, particularly, under inflammatory condition associated autoimmune diseases.

The influence of inflammatory condition on the stability of Treg cells is well manifested by the reversible conversion between Treg cells and T17 cells based on observation that Treg cells treated with IL-6 and IL-1 express IL-17 [88]. Recent studies have indicated that IL-15 can fine tune the balance between the expression of Foxp3 and IL-17 mediated by RAR-related orphan receptor $\gamma \mathrm{t}$, a Th17-specific transcription factor [89, 90]. RA can inhibit Th17 polarization and enhance Foxp3 expression through STAT-3/STAT-5 independent signaling pathway [91]. A recent study has revealed that induction of Treg cells by treatment with RA and TGF- $\beta$ is mediated by miRNAs which can exclusively suppress genes related to differentiation of Th17 cells [60]. Collectively, dynamic plasticity and stability of Treg cells may lead to heterogeneity of Foxp $3^{+}$Treg cell subsets and diversity of responsiveness in immune tolerance and immune homeostasis. Therefore, they should be considered carefully in CTA.

\section{Immune tolerant function of Treg cells in CTA}

Survival of allografts and prevention of chronic rejection are two main goals in CTA.

However, vigorous immune response of Teff cells triggered by alloantigen is the main obstacle to achieve these goals. There are three pathways of alloantigen recognition by Teff cells depending on the pattern of antigen presentation: (1) in a direct pathway, recipient TCR recognizes donor antigen bound to donor MHC molecule presented by donor APCs; (2) in an indirect pathway, recipient TCR recognizes donor antigen bound to recipient $\mathrm{MHC}$ molecule presented by recipient APCs; (3) in a semi-direct pathway, recipient TCR recognizes donor antigen bound to donor MHC molecule presented by recipient APCs [92]. It has been suggested that the direct pathway participates in acute graft allorejection whereas the indirect pathway participates in chronic graft allorejection with production of alloantibodies [93]. However, the role of the semi-direct pathway in allotransplantation has not been clearly addressed yet [93]. Treg cell-mediated immune tolerance and tissue damage control in CTA rely on the inhibition of Teff cells that can recognize alloantigens. For Treg cell therapy in CTA, the suppression of Teff cells with adoptive Treg cell transfer might be hampered by a low number of natural Treg cells and anergic phenotypes, thus losing their immunosuppressive function during in vitro expansion. Large scale in vitro expansion of mice and human polyclonal $\mathrm{CD} 4{ }^{+} \mathrm{CD} 25^{+}$Treg 
cells has revealed that their immunosuppressive functions are maintained [81, 94], supporting that their clinical application in CTA might be feasible.

Cumulative evidence has demonstrated that effective immune tolerant Treg cells can function on CTA in preclinical studies $[11,95]$. In early days, studies on histoincompatible thymic epithelium grafts have suggested the immune tolerant potential of Treg cells in allotransplantation [96-98]. Depletion of CD25 $5^{+}$cells at the time of bone marrow transplantation and blocking CTLA- 4 have abrogated the development of tolerance [99], which suggesting an essential role of IL-2 and CTLA4 in immune tolerant Treg cells function. Interestingly, a subset of Treg cells expressing low levels of CD127 are 5 times more potent in tolerance induction in an animal model of transplanted arteriosclerosis by inhibition of Teff cell function and graft infiltrations [100]. Since the phenomenon of arteriosclerosis in transplantation is considered as a model of chronic transplantation rejection, this result indicates that Treg cells might have potency in long term immune tolerance. Accordingly, Treg cells sorted for the expression of $\mathrm{CD} 4{ }^{+} \mathrm{CD} 25^{+} \mathrm{CD} 127^{\text {low }}$ have displayed potent immune suppressive capability compared to conventional $\mathrm{CD} 25{ }^{\mathrm{hi}} \mathrm{CD} 4{ }^{+}$Treg cells. The contribution of host Treg cell population to induction of immune tolerance has been observed in hepatic allografts model in human and mice systems compared to transplantation rejected model and bone marrow allografts [101, 102]. Therefore, boosting the number of recipient Treg cells might have favorable outcomes in CTA. On the other hand, rapid development of lethal graft-versus-host disease (GVHD) has been observed after administration of cultured $\mathrm{CD} 4{ }^{+} \mathrm{CD} 25^{+} \mathrm{T}$ cells with an equal number of $\mathrm{CD}^{+} \mathrm{T}$ cells or CD25 depleted whole T cells [103]. In addition, the level of Treg cells in peripheral blood does not predict outcomes of transplantation in a nonhuman primate model [104].

Although application of Treg cells in induction of immune tolerance could be an advantage in CTA by minimizing or replacing non-specific immunosuppressive drugs, concerns have been raised about the possibility that the use of naturally occurring polyclonal Treg cells might cause systemic non-specific immunosuppression. In this regard, generation of antigen-specific Treg cells that can selectively induce immune suppression against donor antigen is highly encouraged. Such cells have demonstrated high efficacy $[81,105,106]$. Treg cells with indirect allospecificity for the A2 peptide with autologous DCs have shown potent antigenspecific suppression of skin allografts than polyclonal Tregs cells in the human and mice systems [107, 108]. Treg cells exposed to defined antigens can prevent the rejection of fully allogeneic skin grafts. Mice receiving skin allografts have shown expanded Treg cells that are preferentially accumulated in graft-draining lymph nodes or within the graft, suggesting the efficacy of donor antigen-specificity in transplant tolerance [109]. It has been reported that co-culture of naive $\mathrm{CD}_{4}^{+} \mathrm{T}$ cells and allogeneic antigen presenting cells (APCs) with TGF- $\beta$, RA and IL-2 can induce alloantigen-specific Treg cells with immunosuppressive function in skin allografts [110]. In stably engrafted skin transplants, introduction of Treg cells into mixed lymphocyte reaction had led to suppression of donor-directed $\mathrm{T}$ cell responses with increase of Foxp $3^{+}$cellular infiltrates $[36,111]$. In addition, functional roles of surface molecules expressed on Treg cells have been addressed. It has been reported that Treg cells generated by exposure to an alloantigen in the peripheral blood that can prevent allograft rejection are mediated by CTLA-4 and IL-10-dependent pathways [112]. The clinical potential of infused Tregs cells and their subsequent prevention of acute and chronic allograft rejection have been investigated as follows. Treg cells specific for direct presentation of donor-antigens have failed to prevent chronic allograft rejection. However, Treg cells specific for indirect presentation of donor-antigens fully prevented chronic allograft rejection [105]. Treg cells with indirect allospecificity given by transduction of TCR genes that can confer specificity for MHC class II molecules have led to substantially greater efficacy in transplantation tolerance [113]. These findings implicate that overcoming immunological barriers would be crucial to have efficacious immune tolerance in allotransplantation. Application of donor antigen-specific Treg cells has proved its efficacy in CTA with antigen-specific immune suppression.

\section{Effect of skin resident cells on Treg cells}

CTA is a complex process that involves coordinated innate and adaptive immune responses with multiple mechanisms. Skin is the primary target of CTA. It has extreme antigenicity compared to organ transplantation [114]. High levels of alloreactive memory $\mathrm{T}$ cells in the skin of sensitized recipient are formidable barriers to allotransplantation tolerance in nonprimates and human [115]. Accumulating evidence has indicated that direct modulation of Treg cells by skin resident cells, including DCs, memory Treg cells, macrophages, mast cells, and dermal cells may contribute to successful CTA (Table 1).

The function of DCs is notable in that deletion of Langerhans cells and dermal DCs will reduce immune tolerance. Therefore, their combined application with Treg cells seems encouraging $[129,130]$. Previously, our lab has reported that tolerogenic DCs can prolong hind limb allografts survival when they are co-treated with FK506 [131]. Interestingly, DCs interacting with Treg 
Table 1 Skin-resident cells interacting with Treg cells

\begin{tabular}{|c|c|c|}
\hline Cell type & Action & References \\
\hline \multirow[t]{3}{*}{ Langerhans cells } & Activate and proliferate Treg cells in resting state; limit activation of Treg cells in presence of pathogen & [116] \\
\hline & Induce Treg cells favoring flora tolerance with limited antigens presentation & [117] \\
\hline & Induce Treg cells by secretion of IL-10 and TGF- $\beta$ & [118] \\
\hline \multirow[t]{2}{*}{ Memory Treg cells } & $\begin{array}{l}\text { Localize to hair follicles } \\
\text { Non-migratory and non-responsive in normal skin } \\
\text { Proliferate and produce IL-17 in inflamed skin }\end{array}$ & [119] \\
\hline & $\begin{array}{l}\text { Are activated, proliferated and differentiated into potent suppressor } \\
\text { Attenuate autoimmune reactions in tissues upon repeated responses to antigens }\end{array}$ & [120] \\
\hline \multirow[t]{2}{*}{ Macrophages } & $\begin{array}{l}\text { Promote expression of the chemokine CCL22 } \\
\text { Induce migration and activation of Treg cells }\end{array}$ & [121] \\
\hline & $\begin{array}{l}\text { Express M2-like TIM-4 }{ }^{\text {hi }} \mathrm{CD} 169^{+} \\
\text {Act immunoregulatory function and promote engraftment of cardiac allografts }\end{array}$ & [122] \\
\hline \multirow[t]{2}{*}{ Mast cells } & Act as intermediate at Treg cells dependent allograft tolerance via IL-9 & [123] \\
\hline & Counteract Treg cell function through IL-6 and OX40/OX40L axis toward Th17 cell differentiation & [124] \\
\hline Dermal dendritic cells & Are capable of antigen capture and presentation to $\mathrm{CD}^{+} \mathrm{T}$ cells and Treg cells generation & {$[125]$} \\
\hline Dermal regulatory cells & Induce Treg cells through PD-1 engagement with expression of $\mathrm{ABCB}^{+}$molecules & {$[126]$} \\
\hline Dermal fibroblasts & Induce proliferation of natural Treg cells with IL-15 & {$[127]$} \\
\hline Dermal stromal cells & Express $\mathrm{CD} 90^{+}$and induce Tregs cells & {$[128]$} \\
\hline
\end{tabular}

CCL chemokine ligand, TIM T cell immunoglobulin mucin, ABCB5 ATP binding cassette subfamily $B$ member 5

cells in the skin are twice prevalent compared to those in peripheral blood [9]. Unconventional NK T cells can rapidly produce pro-inflammatory or anti-inflammatory cytokines in response to their cognate glycolipids antigens presented on CD1 molecules [132]. They are most frequently found in the liver $(30-50 \%)$. However, their presence in the skin is not well reported. It has been reported that human skin NK T cells have $1.72-33 \%$ of cellular infiltrates in allergic contact dermatitis [133]. They produce IL-4 and IL-10 that can induce tolerogenic DCs and lead to expansion of Treg cells [134]. In addition, changes in expression of negative costimulatory receptors and anti-inflammatory cytokines by Treg cells in an IL-4-dependent manner can be promoted by NK $\mathrm{T}$ cells, resulting in tolerance to bone marrow and organ grafts [135]. In GVHD mice, bone marrow NK T cells can inhibit the acute lethal immune response by augmenting proliferation of donor-derived Treg cells in an IL-4-dependent manner [136, 137]. This suggests that NK T cells can induce immune tolerance. However, NK cell function in induction of immune tolerance does not seem supportive in which CD28-mediated conversion of $\mathrm{CD} 4{ }^{+} \mathrm{CD} 25^{-} \mathrm{T}$ lymphocytes into $\mathrm{CD} 4{ }^{+} \mathrm{CD} 25^{+}$Treg cells is inhibited by the release of IFN- $\gamma$ [138]. More convincingly, direct lysis of activated Treg cells in response to microbial antigen is NKG2D- and NKp46-dependent, suggesting that NK cells have inhibitory effect on immune tolerance [139]. The positive role of APCs including macrophages, DCs, and B cells in CTA is also highly possible based on following findings. Studies on the regulatory role of macrophages have revealed that tacrolimus can contribute to graft survival and kidney transplantation without having deleterious effects [140]. Moreover, induction of Treg cells with direct allospecificity by tolerogenic DCs to prevent transplantation rejection is encouraging [141]. However, the role of B cells on allotrasplantation is unclear with positive and sometimes negative function. Studies have shown that B cells can produce IL-10 during inflammation and organ transplantation and cause the conversion from Tconv cells to $\operatorname{Tr} 1$ cells, thus preventing transplantation rejection [142, 143]. The function of B cells in expanding Treg cells with the requirement of TGF- $\beta$ in signaling through TCR and CD28 has been reported [144]. In addition, when purified Treg cells are stimulated by CD40L-activated allogeneic $B$ cells and expanded ex vivo with IL-2, greater protection against skin damage has been demonstrated in a humanized mouse model [145]. On the other hand, a contradictory result has been shown in the patient with the first human full face transplantation [146]. Class II-donor specific antibodies were developed at 90 months after transplantation with deposition of $\mathrm{C} 4 \mathrm{~d}$ in demal vessels, followed by skin rejection [147]. This suggests that B cells play a dual role (immune induction and immune tolerance) in transplantation regulation. Evidently, these findings suggest that innate or adaptive immune cells in the skin are important immune modulators. They may reinforce the feasibility of CTA in association with Tregs cells or independently. Further studies may clearly elucidate the path involved. 


\section{Effect of immunosuppressive drugs on Treg cells}

The outstanding efficacy of immune suppressive drugs for suppression of transplantation rejection has been remarkable and indispensable. However, nonspecific immunosuppression has side effects. To replace or minimize their side effects, attempts have been made vigorously. Ex vivo expanded Treg cells with tacrolimus, mycophenolate, and methylprednisolone, the three mostly used immunosuppressive drugs in transplantation clinic, have been investigated in preclinical model. Methylprednisolone reduces inflammatory reaction that may favor Treg cell function. Mycophenolate inhibits $\mathrm{T}$ and B cell proliferation without effect on Tregs. However, tacrolimus is detrimental on Treg cell function and survival [148]. The inhibitory effect of tacrolimus on the calcineurin pathway that lead to IL-2 production has been observed in the early phase of proliferation of Teff cells induced by IL- 2 and in the late phase of survival of Tregs cells induced by IL-2 [47, 149, 150]. In addition, low dose IL-2 therapy that can selectively target Treg cells has shown positive outcomes in patients with Type 1 diabetes mellitus (DM) in clinical settings [151]. With tacrolimus, a population of human Treg cells expressing $\mathrm{CD} 4{ }^{+} \mathrm{CD} 127^{- \text {llow }} \mathrm{CD} 5^{+} \mathrm{CD} 45 \mathrm{RA}{ }^{+}$Treg cells has stable TSDR demethylated FOXP3 ${ }^{+}$phenotype. They can maintain strong suppressive activity against CD4 Teff cell proliferation after expansion, suggesting that a defined population of Treg cells might be effective as therapeutic application by responding to tacrolimus [152]. It is noteworthy that rapamycin, an inhibitor of mTOR, can maintain the viability, function, and proliferative ability of adoptively transferred Treg cells in allotransplantation. It can induce Tregs cells in both healthy volunteers and patients with type I DM [153]. mTOR activation is essential for T cell commitment to Th1, Th2, and Th17 effector lineages. However, naive $\mathrm{T}$ cells preferentially differentiate into Treg cells in absence of mTOR [154]. Rapamycin can inhibit mTOR pathway as well as Smad7, a negative regulator of TGF- $\beta$ signaling. Accordingly, adoptive transfer of a small number of alloantigen-specific Treg cells along with low dose of rapamycin has induced longterm survival of cardiac allografts in mice [155], thus, providing an informative regimen for Treg cell therapy with rapamycin. Taken together, immune tolerance function of Tregs in CTA can be synergized with immunosuppressive drugs such as tacrolimus and rapamycin.

\section{Therapeutic application of Treg cells in the clinic Ex vivo expansion of Treg cells for adoptive transfer}

Isolation of blood Treg cells, expansion in ex vivo system, and reinfusion modalities have been attractive goals to increase the feasibility and efficacy of Treg cell therapy [148]. To have quality production of Treg cells for clinical use, Good Manufacturing Product (GMP) facilities are mandatory. They should fulfill safety concern and generate clinically relevant number of Treg cells with maximum purity that can abundantly express Foxp3 without secreting pro-inflammatory cytokines [156]. Although it is challenging, in vitro expansion protocols have been established by several groups for polyclonal Treg cells and antigen-specific Treg cells from peripheral blood and umbilical cord blood after apheresis, respectively [81, 94, 157, 158]. About $2-10 \%$ of $\mathrm{CD}^{+} \mathrm{T}$ cells are present in human Treg cells. However, only $0.25 \times 10^{9}$ Treg cells among the total number of $13 \times 10^{9}$ Treg cells are circulating in the blood [159]. To isolate Treg cells, $\mathrm{CD} 4{ }^{+} \mathrm{CD} 25^{+} \mathrm{T}$ cells are selected following the depletion of $\mathrm{CD}^{+}, \mathrm{CD}_{1} 4^{+}$, and $\mathrm{CD} 19^{+}$cells after depleting $\mathrm{CD}^{+} \mathrm{T}$ cells, monocytes, and $\mathrm{B}$ cells using antibodycoated magnetic-beads, respectively. A positive selection step is then used to enrich $\mathrm{CD} 4{ }^{+} \mathrm{CD} 25^{+} \mathrm{T}$ cells using a sub-saturating concentration of anti-CD4 antibody and anti-CD25 antibody to capture the $\mathrm{CD} 4^{+}$and $\mathrm{CD} 25^{\text {bright }}$ fractions. In the preparation of $\mathrm{CD} 4^{+} \mathrm{CD} 25^{+} \mathrm{Foxp} 3^{+}$ Treg cells, no consensus procedure has been set up yet. Up to date, the following four types of GMP-grade clinical Treg cells have been proposed depending on surface marker: $\mathrm{CD} 4^{+} \mathrm{CD} 25^{+} \mathrm{T}$ cells, bona fide Treg cells expressing $\mathrm{CD} 4{ }^{+} \mathrm{CD} 25^{+} \mathrm{CD} 127^{\text {low/- }}$, naïve Treg cells expressing $\mathrm{CD} 4{ }^{+} \mathrm{CD} 25^{+} \mathrm{CD} 127^{\text {low } /-} \mathrm{CD} 45 \mathrm{RA}^{+}$, and $\mathrm{CD}^{+} \mathrm{CD} 25^{+} \mathrm{CD} 127^{\text {low } /-} \mathrm{GARP}^{+} \mathrm{LAP}^{+}$[160]. Although human and murine Treg cells are anergic and unsuitable for large-scale expansion, studies have shown that supplementation of high-dose IL-2 in combination with TCR- and CD28-mediated stimulation is suffcient to promote their in vitro proliferation [94]. Up to date, most adoptive Treg cell therapy studies have used $\mathrm{CD} 4^{+} \mathrm{CD} 25^{++}$or $\mathrm{CD} 4^{+} \mathrm{CD} 25^{+} \mathrm{CD} 127^{-}$Treg cells. It is possible that Treg cell subset appropriateness will vary depending on the application. In addition, it has been reported that $\mathrm{CD} 4{ }^{+} \mathrm{CD} 25^{\text {high }} \mathrm{CD} 45 \mathrm{RA}^{+}$Treg cells are ideal as starting population for the generation of homogeneous and stable Treg cells [161]. In GVHD, large-scale expanded human iTreg cells have successfully manifested their immune suppressive functions [162], indicating that Treg cell therapy is promising in CTA.

\section{Production of donor antigen-specific Treg cells}

As highlighted in preclinical model studies, antigen-specific Treg cells have higher potency in suppressing undesired immune responses compared to polyclonal Treg cells. To produce donor antigen-specific Treg cells, DCs, $\mathrm{B}$ cells, and PBMCs have been used [163]. To prepare allogenic DCs-specific Treg cells, CD $4{ }^{+} \mathrm{CD} 25^{+} \mathrm{CD} 127^{\text {low }}$ $\mathrm{T}$ cells derived from PBMCs in the recipient have been treated with $\mathrm{CD}^{+} \mathrm{c}^{+}$dermal DCs derived from donor 
skin. After priming with DCs in mixed lymphocyte reaction and stimulation with CD3 and CD28 antibodies, enriched and expanded donor antigen-specific Treg cells with expression of $\mathrm{CD} 9^{+} \mathrm{CD} 71^{+}$can be harvested [164]. For $\mathrm{B}$ cells, alloantigenicity can be obtained by stimulation with CD40L-activated allogeneic B cells from the donor or allogeneic human leukocyte antigen (HLA) [165]. Manufacturing and clinical trials of antigen-specific Treg cells therapy to induce immune tolerance in allotransplantation and autoimmune diseases are underway $[160,163]$.

Alternatively, antigen-specific Treg cell therapy using chimeric antigen receptor (CAR) expression system has generated interest. Human Treg cells engineered to create HLA-A2-specific CAR have prevented xenogeneic GVHD in mice model [166], suggesting promising perspectives. CAR-Treg-cell therapy targeting donor antigen with enhanced immunosuppressive activity has been demonstrated in autoimmune diseases. It has efficiently prevented autoimmune encephalitis (EAE), colitis, and immune responses to factor VIII in hemophilia A [167169]. Another approach involves the engineering of TCR gene to induce tolerance in CTA in a rodent model. In this approach, $\mathrm{CD} 4{ }^{+} \mathrm{CD} 25^{+}$Treg cells with indirect allospecificity can be generated by retroviral transduction of TCR genes specific for allogeneic MHC class II. Induction of indefinite heart allograft survival with short-term systemic immunosuppression in partially MHC mismatched heart allografts combined with immunosuppressive drugs has been reported [113]. With the goal to manipulate TCR gene as therapeutics, RNA-interference and genome editing technique using transcription activator-like effector nucleases to increase efficacy and safety have been attempted [170]. These data collectively suggest that CAR-Treg cells and modifying TCR gene might be useful for CTA clinically in the future.

\section{Clinical trials of Treg cells}

So far, 322 clinical trials of Treg cell therapy have been listed on http://www.ClinicalTrials.gov registry at the time of writing this article (31-07-2017). However, none of them involves CTA. Nevertheless, current ongoing clinical trials of Treg cell therapy targeting induction of immune tolerance in organ transplantation and autoimmune disease may provide valuable lessons. Recent outcomes after phase I clinical trial of polyclonal Treg cells in patients with Type I diabetes mellitus (DM) have proved its safety [171]. Undergoing clinical trials of Treg cell therapy for allotransplantation and autoimmune diseases include kidney and liver transplantation, GVHD, Type I DM, Lupus, and other autoimmune-related diseases with polyclonal or donor antigen-specific Treg cells [160]. Given the superior efficacy of antigen-specific
Treg cells with direct allospecificity in preclinical studies compared to polyclonal Treg cells, antigen-specific Treg cells have a favorable position in allotransplantation [164]. Regarding immune modulatory function, donor antigen-specific Treg cells have an advantage of immune site specific distribution against alloantigens and induction of immune tolerance. Thus, they could be, particularly, effective for CTA. In adoptive Treg cell transfer and immune tolerance, the following factors might contribute to graft acceptance: (1) time frame for infusion of Treg cells shortly before or at the time of transplantation or during a graft rejection episode, (2) mixed ratio of Treg cells to Teff cells for adoptive transfer of Treg cells in which Teff cells play a role in maintaining recipient's immunity, and (3) co-treatment with immunosuppressive drugs, co-stimulatory molecule blockades, or/and cytokines. Indeed, the field of CTA is growing. Eliminating side effects caused by immunosuppressive drugs with Treg cells will nurture the field of allotransplantation in general. A schematic representation of Treg cells development pathways, human Treg cell expressing markers, and workflow of therapeutic application of antigen-specific Treg cells in CTA is shown in Fig. 1.

\section{Conclusions}

CTA and organ transplantation share a common concept of alloimmunity. However, studies on CTA have revealed its unique characteristics different from organ transplantation as follows. First, rejection rate of hand or skin transplantation is exceptionally high. About $85-95 \%$ of patients experience transplantation rejection within a year, in sharp contrast to organ transplantation whose rejection rate is less than $10 \%$. Second, CTA shows a tendency of resistance in spite of treatment with immunosuppressive drugs compared to organ transplantation which shows immune susceptibility. Third, CTA comprises multiple layers of tissues compared to organ transplantation which has rather homogeneous parenchyma. Fourth, monitoring transplantation immune rejection in CTA is relatively easy and visible.

Prevention of acute allorejection and long term survival of grafted tissues are two ultimate goals in CTA. Although the development and advancement of immunosuppressive drugs have changed the paradigm for allotransplantation and broke barriers for MHC class antigens in immune recognition, lifelong medication of non-antigen-specific immunosuppressive drugs and their side effects pose serious health issues. In this regard, application of Treg cells, particularly the generation of donor antigen-specific Treg cells to induce immune tolerance is an attractive task in allotransplantation of organs or tissues. Considering that CTA shows exceptionally high antigenicity, the strategy of inducing immune 


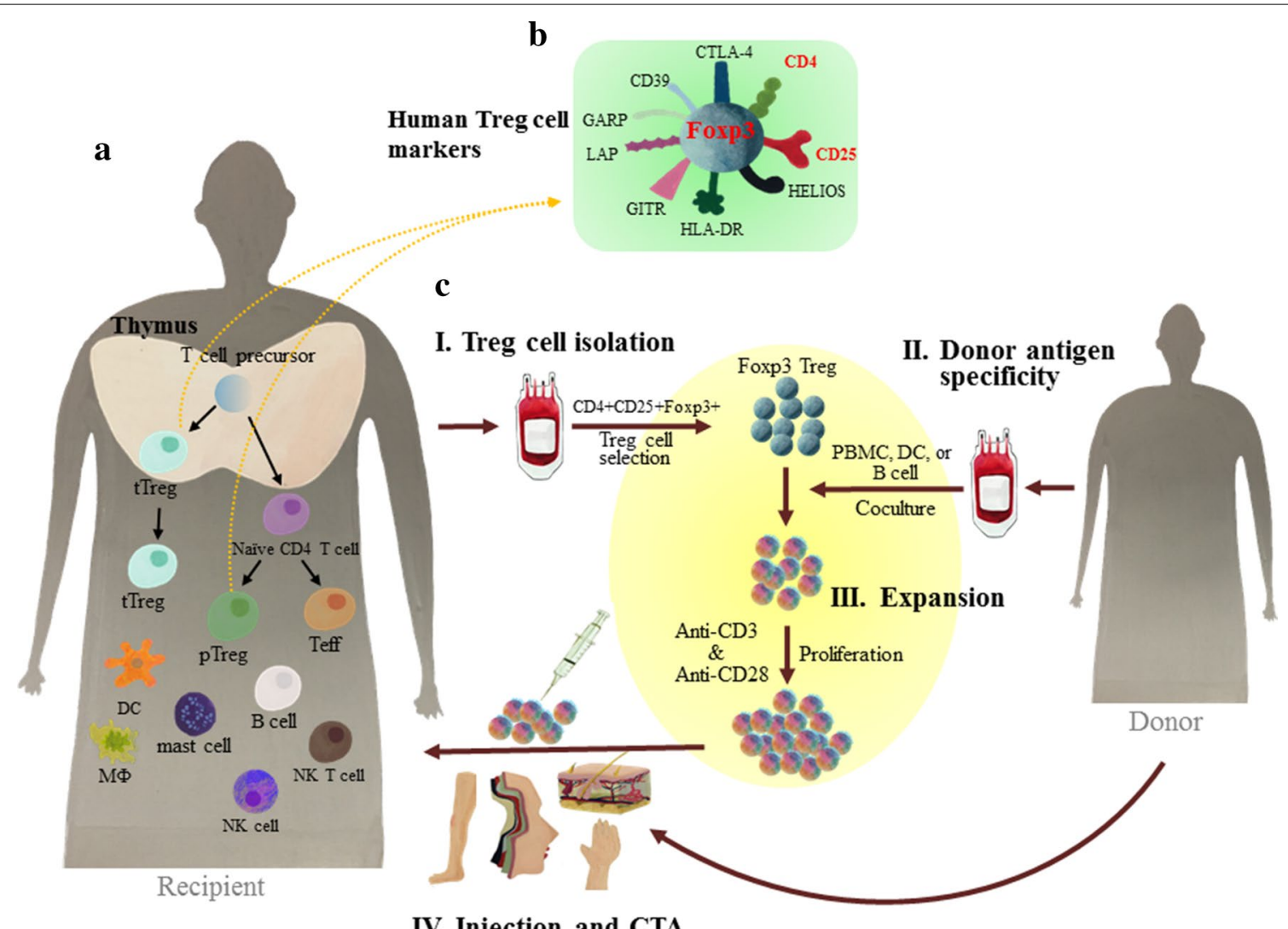

IV. Injection and CTA

Fig. 1 a Treg cells development pathways, b human Treg cell expressing markers, and c workflow of therapeutic application of donor antigen-specific Treg cells in CTA. a Treg cells development pathways. In the thymus, T cell precursors derived from bone marrow progenitor cells are developed into thymic Treg (tTreg) cells and exported to the periphery. Peripheral Treg (pTreg) cells are induced by naïve $\mathrm{CD}^{+}{ }^{+} \mathrm{CD} 25^{-} \mathrm{T}$ cells. b $\mathrm{Human}$ Treg cells expressing markers. Expression of CD4, CD25, FoxP3, CLTA-4, CD39, HLA-DR, LAP, GARP, and HELIOS is frequently observed in human Treg cells. c A workflow of therapeutic application of donor antigen-specific Treg cells in CTA. As a positive selection step to enrich CD4 ${ }^{+} \mathrm{CD} 25^{+}$Foxp $3^{+}$Treg cells, a sub-saturating concentration of anti-CD4 antibody and anti-CD25 antibody is used to capture CD4+ and CD25 bright fractions (I, isolation). To produce donor antigen-specific Treg cells, DCs (or APCs), B cells, or peripheral blood mononuclear cells (PBMCs) are applied (II, antigen-specificity). After priming in mixed lymphocyte reaction, Treg cells are stimulated with anti-CD3 antibody and anti-CD28 antibody for enrichment and expansion (III, expansion). Finally, expanded Treg cells are injected back to the recipient in CTA (IV, Treg cells injection and CTA)

tolerance with Treg cells by controlling skin antigenicity seems desirable. Cumulative evidence has demonstrated its feasibility in preclinical studies. Currently, Treg cell therapy is being applied in clinical trials of organ transplantation and autoimmune diseases. However, clinical trial of Treg cell therapy has not been conducted in CTA yet. For adoptive transfer of Treg cells in therapeutics, issues concerning safety and quality control of functional Treg cells are beyond requirement. Particularly, expansion of GMP grade Treg cells with maximum purity that abundantly express Foxp3 without secreting pro-inflammatory cytokines is the first priority. Although Foxp3 is regarded as a gold standard for Treg cells expressing CD25, it has limitation because the expression of Foxp3 and CD25 can be easily altered in Tconv cells under inflammatory conditions. Identification of bona fide
Treg cells expressing reliable markers is eagerly awaited for effective Treg cell therapy in allotransplantation. In addition, development of biomarkers to precisely measure the degree of engraftment and predict the progress of chronic rejection in a timely manner is essential for early intervention in CTA.

\footnotetext{
Abbreviations

APCs: antigen presenting cells; CAR: chimeric antigen receptor; CCR4: c-cmotif chemokine receptor-4; $C D$ : cluster of differentiation; $C 4 \mathrm{~d}$ : complement 4d; CLA: cutaneous lymphocyte antigen; CTA: composite tissue allotransplantation; DCs: dendritic cells; DM: diabetes mellitus; Foxp3: forkhead box P3; GARP: garpin protein; GITR: glucocorticoid-induced tumor-necrosis factor (TNF)-receptor-related protein; GMP: good manufacturing product; GVHD: graft versus host disease; HLA: human leukocyte antigen; IL-2: interleukin-2; LAP: latency associated-peptide; MHC: major histocompatibility complex; mTOR: mammalian target of rapamycin; NFAT: nuclear factor of activated T cell; NF-kB: the nuclear factor-kappa B; NK: natural killer; PBMCs: peripheral blood mononuclear cells; NRP-1: neuropilin 1; PD-1: programmed death-1; RA:
} 
retinoic acid; STAT: signal transducer and activator of transcription; Tconv cell: conventional T cell; TCR: T cell receptor; TGF- $\beta$ : transforming growth factor- $\beta$; Th1 cell: type 1 helper cell; $\operatorname{Tr} 1$ cell: type 1 regulatory $T$ cell; $T_{\text {EM }}$ cell: effector memory T cell; Treg cell: T regulatory cell.

\section{Authors' contributions}

JY designed, structured, and wrote the manuscript. SE designed and reviewed the manuscript. Both authors read and approved the final manuscript.

\section{Acknowledgements}

We appreciate Ms. Juri Na for her help in the illustration work.

\section{Competing interests}

The authors declare that they have no competing interests.

\section{Availability of data and materials}

Not applicable.

\section{Consent for publication}

The authors have read this manuscript and provided consent for publication.

\section{Ethics approval and consent to participate}

Not applicable.

\section{Funding}

Not applicable.

\section{Publisher's Note}

Springer Nature remains neutral with regard to jurisdictional claims in published maps and institutional affiliations.

Received: 6 August 2017 Accepted: 20 October 2017

Published online: 26 October 2017

\section{References}

1. Dubernard JM, Owen E, Herzberg G, Lanzetta M, Martin X, Kapila H, Dawahra M, Hakim NS. Human hand allograft: report on first 6 months. Lancet. 1999;353:1315-20.

2. Dubernard JM, Lengele B, Morelon E, Testelin S, Badet L, Moure C, Beziat JL, Dakpe S, Kanitakis J, D'Hauthuille C, et al. Outcomes 18 months after the first human partial face transplantation. N Engl J Med. 2007:357:2451-60.

3. Kueckelhaus M, Fischer S, Seyda M, Bueno EM, Aycart MA, Alhefzi M, ElKhal A, Pomahac B, Tullius SG. Vascularized composite allotransplantation: current standards and novel approaches to prevent acute rejection and chronic allograft deterioration. Transpl Int. 2016;29:655-62.

4. Sosin M, Rodriguez ED. The face transplantation update: 2016. Plast Reconstr Surg. 2016;137:1841-50.

5. Swearingen B, Ravindra K, Xu H, Wu S, Breidenbach WC, Ildstad ST. Science of composite tissue allotransplantation. Transplantation. 2008;86:627-35.

6. Eun SC. Composite tissue allotransplantation immunology. Arch Plast Surg. 2013:40:141-53.

7. Klimczak A, Siemionow M. Immune responses in transplantation: application to composite tissue allograft. Semin Plast Surg. 2007;21:226-33.

8. Petruzzo P, Lanzetta M, Dubernard JM, Landin L, Cavadas P, Margreiter R, Schneeberger S, Breidenbach W, Kaufman C, Jablecki J, et al. The international registry on hand and composite tissue transplantation. Transplantation. 2010;90:1590-4.

9. Chadha R, Leonard DA, Kurtz JM, Cetrulo CL Jr. The unique immunobiology of the skin: implications for tolerance of vascularized composite allografts. Curr Opin Organ Transplant. 2014;19:566-72.

10. Saidi RF, Hejazii Kenari SK. Clinical transplantation and tolerance: are we there yet? Int J Organ Transplant Med. 2014;5:137-45.

11. Sakaguchi $\mathrm{S}$. Naturally arising $\mathrm{CD} 4^{+}$regulatory t cells for immunologic self-tolerance and negative control of immune responses. Annu Rev Immunol. 2004;22:531-62.
12. Issa F, Wood KJ. The potential role for regulatory T-cell therapy in vascularized composite allograft transplantation. Curr Opin Organ Transplant. 2014;19:558-65.

13. LeGuern C, Akiyama Y, Germana S, Tanaka K, Fernandez L, Iwamoto Y, Houser S, Benichou G. Intracellular MHC class II controls regulatory tolerance to allogeneic transplants. J Immunol. 2010;184:2394-400.

14. Scalea JR, Okumi M, Villani V, Shimizu A, Nishimura H, Gillon BC, Torabi R, Cormack T, Moran S, LeGuern C, et al. Abrogation of renal allograft tolerance in MGH miniature swine: the role of intra-graft and peripheral factors in long-term tolerance. Am J Transplant. 2014;14:2001-10.

15. Josefowicz SZ, Lu LF, Rudensky AY. Regulatory T cells: mechanisms of differentiation and function. Annu Rev Immunol. 2012;30:531-64.

16. Camirand G, Riella LV. Treg-centric view of immunosuppressive drugs in transplantation: a balancing act. Am J Transplant. 2016;17(3):601-10.

17. Jones JW, Gruber SA, Barker JH, Breidenbach WC. Successful hand transplantation. One-year follow-up. Louisville hand transplant team. N Engl J Med. 2000;343:468-73.

18. Kupper TS, Fuhlbrigge RC. Immune surveillance in the skin: mechanisms and clinical consequences. Nat Rev Immunol. 2004;4:211-22.

19. Heath WR, Carbone FR. The skin-resident and migratory immune system in steady state and memory: innate lymphocytes, dendritic cells and T cells. Nat Immunol. 2013:14:978-85.

20. Dvorak HF, Mihm MC Jr, Dvorak AM, Barnes BA, Manseau EJ, Galli SJ. Rejection of first-set skin allografts in man. the microvasculature is the critical target of the immune response. J Exp Med. 1979;150:322-37.

21. Bhan AK, Mihm MC Jr, Dvorak HF. T cell subsets in allograft rejection. In situ characterization of T cell subsets in human skin allografts by the use of monoclonal antibodies. J Immunol. 1982;129:1578-83.

22. Lian CG, Bueno EM, Granter SR, Laga AC, Saavedra AP, Lin WM, Susa JS, Zhan Q, Chandraker AK, Tullius SG, et al. Biomarker evaluation of face transplant rejection: association of donor T cells with target cell injury. Mod Pathol. 2014;27:788-99.

23. Larsen CP, Steinman RM, Witmer-Pack M, Hankins DF, Morris PJ, Austyn $J M$. Migration and maturation of Langerhans cells in skin transplants and explants. J Exp Med. 1990;172:1483-93.

24. Hoffman DK, Sibley RK, Korman JM, Press BH. Light microscopic and immunohistochemical features in serial biopsies of epidermal versus dermal allografts. Ann Plast Surg. 1994;33:295-9.

25. Mueller SN, Zaid A, Carbone FR. Tissue-resident T cells: dynamic players in skin immunity. Front Immunol. 2014;5:332.

26. Clark RA, Chong B, Mirchandani N, Brinster NK, Yamanaka K, Dowgiert RK, Kupper TS. The vast majority of $\mathrm{CLA}^{+} \mathrm{T}$ cells are resident in normal skin. J Immunol. 2006;176:4431-9.

27. Li J, Olshansky M, Carbone FR, Ma JZ. Transcriptional analysis of T cells resident in human skin. PLoS ONE. 2016;11:e0148351.

28. Leonard DA, Kurtz JM, Cetrulo CL Jr. Vascularized composite allotransplantation: towards tolerance and the importance of skin-specific immunobiology. Curr Opin Organ Transplant. 2013;18:645-51.

29. Cetrulo CL Jr, Torabi R, Scalea JR, Shimizu A, Leto Barone AA, Gillon BC, Tasaki M, Leonard DA, Cormack TA, Villani V, et al. Vascularized composite allograft transplant survival in miniature swine: is MHC tolerance sufficient for acceptance of epidermis? Transplantation. 2013;96:966-74.

30. Lee WP, Yaremchuk MJ, Pan YC, Randolph MA, Tan CM, Weiland AJ. Relative antigenicity of components of a vascularized limb allograft. Plast Reconstr Surg. 1991;87:401-11.

31. Merrill JP, Murray JE, Harrison JH, Guild WR. Successful homotransplantation of the human kidney between identical twins. J Am Med Assoc. 1956;160:277-82.

32. Kaden J, May G, Strobelt V, Groth J, Muller P. Intraoperative T-cell depletion prior to completion of anastomoses by high-dose single ATG bolus as a new approach to improve long-term results after kidney transplantation. Transplant Proc. 1997;29:344-7.

33. Colombo D, Ammirati E. Cyclosporine in transplantation - a history of converging timelines. J Biol Regul Homeost Agents. 2011;25:493-504.

34. Diaz-Siso JR, Bueno EM, Sisk GC, Marty FM, Pomahac B, Tullius SG. Vascularized composite tissue allotransplantation-state of the art. Clin Transplant. 2013;27:330-7.

35. Billingham RE, Brent L, Medawar PB. Actively acquired tolerance of foreign cells. Nature. 1953;172:603-6.

36. Eljaafari A, Badet L, Kanitakis J, Ferrand C, Farre A, Petruzzo P, Morelon E, Dubosson M, Tiberghien P, Dubois V, et al. Isolation of regulatory T cells 
in the skin of a human hand-allograft, up to six years posttransplantation. Transplantation. 2006;82:1764-8.

37. Hester J, Schiopu A, Nadig SN, Wood KJ. Low-dose rapamycin treatment increases the ability of human regulatory $T$ cells to inhibit transplant arteriosclerosis in vivo. Am J Transplant. 2012;12:2008-16.

38. Sakaguchi S, Yamaguchi T, Nomura T, Ono M. Regulatory T cells and immune tolerance. Cell. 2008;133:775-87.

39. Plitas G, Rudensky AY. Regulatory T Cells: differentiation and function. Cancer Immunol Res. 2016:4:721-5.

40. Bennett CL, Christie J, Ramsdell F, Brunkow ME, Ferguson PJ, Whitesell L, Kelly TE, Saulsbury FT, Chance PF, Ochs HD. The immune dysregulation, polyendocrinopathy, enteropathy, X-linked syndrome (IPEX) is caused by mutations of FOXP3. Nat Genet. 2001;27:20-1.

41. Ramsdell F, Ziegler SF. FOXP3 and scurfy: how it all began. Nat Rev Immunol. 2014;14:343-9.

42. Abbas AK, Benoist C, Bluestone JA, Campbell DJ, Ghosh S, Hori S, Jiang S, Kuchroo VK, Mathis D, Roncarolo MG, et al. Regulatory T cells: recommendations to simplify the nomenclature. Nat Immunol. 2013;14:307-8.

43. Lio CW, Hsieh CS. A two-step process for thymic regulatory T cell development. Immunity. 2008;28:100-11.

44. Li MO, Rudensky AY.T cell receptor signalling in the control of regulatory T cell differentiation and function. Nat Rev Immunol. 2016;16:220-33.

45. Hori S, Nomura T, Sakaguchi S. Control of regulatory T cell development by the transcription factor Foxp3. Science. 2003;299:1057-61.

46. Kretschmer K, Apostolou I, Hawiger D, Khazaie K, Nussenzweig MC, von Boehmer $\mathrm{H}$. Inducing and expanding regulatory $T$ cell populations by foreign antigen. Nat Immunol. 2005;6:1219-27.

47. Yadav M, Stephan S, Bluestone JA. Peripherally induced tregs-role in immune homeostasis and autoimmunity. Front Immunol. 2013;4:232.

48. Haribhai D, Williams JB, Jia S, Nickerson D, Schmitt EG, Edwards B, Ziegelbauer J, Yassai M, Li SH, Relland LM, et al. A requisite role for induced regulatory $T$ cells in tolerance based on expanding antigen receptor diversity. Immunity. 2011;35:109-22.

49. Bilate AM, Lafaille JJ. Induced $\mathrm{CD}^{+}{ }^{+} \mathrm{Foxp}^{+}$regulatory T cells in immune tolerance. Annu Rev Immunol. 2012:30:733-58.

50. Schallenberg S, Tsai PY, Riewaldt J, Kretschmer K. Identification of an immediate Foxp3(-) precursor to Foxp3(+) regulatory T cells in peripheral lymphoid organs of nonmanipulated mice. J Exp Med. 2010;207:1393-407.

51. Petzold C, Steinbronn N, Gereke M, Strasser RH, Sparwasser T, Bruder D, Geffers R, Schallenberg S, Kretschmer K. Fluorochrome-based definition of naturally occurring Foxp3(+) regulatory T cells of intra- and extrathymic origin. Eur J Immunol. 2014;44:3632-45.

52. Paiva RS, Lino AC, Bergman ML, Caramalho I, Sousa AE, Zelenay S, Demengeot J. Recent thymic emigrants are the preferential precursors of regulatory T cells differentiated in the periphery. Proc Natl Acad Sci USA. 2013;110:6494-9.

53. Thiault N, Darrigues J, Adoue V, Gros M, Binet B, Perals C, Leobon B, Fazilleau N, Joffre OP, Robey EA, et al. Peripheral regulatory T lymphocytes recirculating to the thymus suppress the development of their precursors. Nat Immunol. 2015;16:628-34.

54. Kendal AR, Chen Y, Regateiro FS, Ma J, Adams E, Cobbold SP, Hori $\mathrm{S}$, Waldmann $\mathrm{H}$. Sustained suppression by Foxp $3^{+}$regulatory ${ }^{\top}$ cells is vital for infectious transplantation tolerance. J Exp Med. 2011;208:2043-53.

55. Waldmann H. Tolerance: an overview and perspectives. Nat Rev Nephrol. 2010;6:569-76.

56. Chen W, Jin W, Hardegen N, Lei KJ, Li L, Marinos N, McGrady G, Wahl SM Conversion of peripheral $\mathrm{CD} 4^{+} \mathrm{CD} 25^{-}$naive $T$ cells to $\mathrm{CD} 4^{+} \mathrm{CD} 25^{+}$regulatory T cells by TGF-beta induction of transcription factor Foxp3. J Exp Med. 2003;198:1875-86.

57. Zheng SG, Wang J, Wang P, Gray JD, Horwitz DA. IL-2 is essential for TGFbeta to convert naive $\mathrm{CD} 4^{+} \mathrm{CD} 25^{-}$cells to $\mathrm{CD} 25^{+}$Foxp $3^{+}$regulatory $T$ cells and for expansion of these cells. J Immunol. 2007:178:2018-27.

58. Tran DQ, Ramsey H, Shevach EM. Induction of FOXP3 expression in naive human $C D 4^{+}$FOXP3 $T$ cells by T-cell receptor stimulation is transforming growth factor-beta dependent but does not confer a regulatory phenotype. Blood. 2007;110:2983-90.
59. Lu L, Zhou X, Wang J, Zheng SG, Horwitz DA. Characterization of protective human CD4CD25 FOXP3 regulatory T cells generated with IL-2. TGF-beta and retinoic acid. PLoS One. 2010;5:e15150.

60. Schiavinato J, Haddad R, Saldanha-Araujo F, Baiochi J, Araujo AG, Santos Scheucher P, Covas DT, Zago MA, Panepucci RA. TGF-beta/atRA-induced Tregs express a selected set of microRNAs involved in the repression of transcripts related to Th17 differentiation. Sci Rep. 2017;7:3627.

61. Lee HM, Bautista JL, Hsieh CS. Thymic and peripheral differentiation of regulatory T cells. Adv Immunol. 2011;112:25-71.

62. Gottschalk RA, Corse E, Allison JP. TCR ligand density and affinity determine peripheral induction of Foxp3 in vivo. J Exp Med. 2010;207:1701-11.

63. Long M, Park SG, Strickland I, Hayden MS, Ghosh S. Nuclear factorkappaB modulates regulatory $T$ cell development by directly regulating expression of Foxp3 transcription factor. Immunity. 2009:31:921-31.

64. Wu Y, Borde M, Heissmeyer V, Feuerer M, Lapan AD, Stroud JC, Bates DL, Guo L, Han A, Ziegler SF, et al. FOXP3 controls regulatory T cell function through cooperation with NFAT. Cell. 2006;126:375-87.

65. Ouyang W, Liao W, Luo CT, Yin N, Huse M, Kim MV, Peng M, Chan P, Ma Q, Mo Y, et al. Novel Foxo1-dependent transcriptional programs control T(reg) cell function. Nature. 2012;491:554-9.

66. Singh K, Hjort M, Thorvaldson L, Sandler S. Concomitant analysis of Helios and Neuropilin-1 as a marker to detect thymic derived regulatory T cells in naive mice. Sci Rep. 2015;5:7767.

67. Szurek E, Cebula A, Wojciech L, Pietrzak M, Rempala G, Kisielow P, Ignatowicz L. Differences in expression level of helios and Neuropilin-1 do not distinguish thymus-derived from extrathymically-induced CD4+Foxp3+ ${ }^{+}$regulatory T cells. PLoS ONE. 2015;10:e0141161.

68. Milpied P, Renand A, Bruneau J, Mendes-da-Cruz DA, Jacquelin S, Asnafi $\checkmark$, Rubio MT, MacIntyre E, Lepelletier Y, Hermine O. Neuropilin-1 is not a marker of human Foxp3 ${ }^{+}$Treg. Eur J Immunol. 2009:39:1466-71.

69. d'Hennezel E, Yurchenko E, Sgouroudis E, Hay V, Piccirillo CA. Single-cell analysis of the human $T$ regulatory population uncovers functional heterogeneity and instability within FOXP3 ${ }^{+}$cells. J Immunol. 2011;186:6788-97.

70. Bin Dhuban K, d'Hennezel E, Nashi E, Bar-Or A, Rieder S, Shevach EM, Nagata S, Piccirillo CA. Coexpression of TIGIT and FCRL3 identifies Helios ${ }^{+}$human memory regulatory T cells. J Immunol. 2015;194:3687-96.

71. Bin Dhuban K, Kornete M, S Mason E, Piccirillo CA. Functional dynamics of Foxp3(+) regulatory T cells in mice and humans. Immunol Rev. 2014;259:140-58.

72. Sakaguchi S, Miyara M, Costantino CM, Hafler DA. FOXP3 ${ }^{+}$regulatory T cells in the human immune system. Nat Rev Immunol. 2010;10:490-500.

73. Feuerer M, Hill JA, Kretschmer K, von Boehmer H, Mathis D, Benoist C. Genomic definition of multiple ex vivo regulatory $T$ cell subphenotypes. Proc Natl Acad Sci USA. 2010;107:5919-24.

74. Jethwa H, Adami AA, Maher J. Use of gene-modified regulatory T-cells to control autoimmune and alloimmune pathology: is now the right time? Clin Immunol. 2014;150:51-63.

75. Gregori S, Goudy KS, Roncarolo MG. The cellular and molecular mechanisms of immuno-suppression by human type 1 regulatory $T$ cells. Front Immunol. 2012;3:30.

76. Fontenot JD, Gavin MA, Rudensky AY. Foxp3 programs the development and function of $\mathrm{CD}_{4}{ }^{+} \mathrm{CD} 25^{+}$regulatory T cells. Nat Immunol. 2003:4:330-6.

77. Allan SE, Crome SQ, Crellin NK, Passerini L, Steiner TS, Bacchetta R, Roncarolo MG, Levings MK. Activation-induced FOXP3 in human T effector cells does not suppress proliferation or cytokine production. Int Immunol. 2007;19:345-54.

78. Barbi J, Pardoll D, Pan F. Treg functional stability and its responsiveness to the microenvironment. Immunol Rev. 2014;259:115-39.

79. Overacre AE, Vignali DA. T(reg) stability: to be or not to be. Curr Opin Immunol. 2016;39:39-43.

80. Wolf KJ, Emerson RO, Pingel J, Buller RM, DiPaolo RJ. Conventional and regulatory $\mathrm{CD}^{+} \mathrm{T}$ cells that share identical TCRs are derived from common clones. PLOS ONE. 2016;11:e0153705.

81. Tang Q, Henriksen KJ, Bi M, Finger EB, Szot G, Ye J, Masteller EL, McDevitt $\mathrm{H}$, Bonyhadi M, Bluestone JA. In vitro-expanded antigen-specific 
regulatory T cells suppress autoimmune diabetes. J Exp Med. 2004;199:1455-65.

82. Hoffmann P, Boeld TJ, Eder R, Huehn J, Floess S, Wieczorek G, Olek S, Dietmaier W, Andreesen R, Edinger M. Loss of FOXP3 expression in natural human $C D 4^{+} \mathrm{CD} 25^{+}$regulatory $T$ cells upon repetitive in vitro stimulation. Eur J Immunol. 2009;39:1088-97.

83. Bailey-Bucktrout SL, Bluestone JA. Regulatory T cells: stability revisited. Trends Immunol. 2011;32:301-6.

84. Thomson AW, Turnquist HR, Raimondi G. Immunoregulatory functions of mTOR inhibition. Nat Rev Immunol. 2009;9:324-37.

85. Ohkura N, Hamaguchi M, Morikawa H, Sugimura K, Tanaka A, Ito Y, Osaki M, Tanaka Y, Yamashita R, Nakano N, et al. T cell receptor stimulationinduced epigenetic changes and Foxp3 expression are independent and complementary events required for Treg cell development. Immunity. 2012;37:785-99.

86. Polansky JK, Kretschmer K, Freyer J, Floess S, Garbe A, Baron U, Olek S, Hamann A, von Boehmer $\mathrm{H}$, Huehn J. DNA methylation controls Foxp3 gene expression. Eur J Immunol. 2008;38:1654-63.

87. Braza F, Dugast E, Panov I, Paul C, Vogt K, Pallier A, Chesneau M, Baron D, Guerif P, Lei H, et al. Central role of CD45RA - Foxp3hi memory regulatory $\mathrm{T}$ cells in clinical kidney transplantation tolerance. J Am Soc Nephrol. 2015;26:1795-805.

88. Wan YY. Regulatory T cells: immune suppression and beyond. Cell Mol Immunol. 2010;7:204-10.

89. Tosiek MJ, Fiette L, El Daker S, Eberl G, Freitas AA. IL-15-dependent balance between Foxp3 and RORgammat expression impacts inflammatory bowel disease. Nat Commun. 2016;7:10888.

90. Kitani A, Xu L. Regulatory T cells and the induction of IL-17. Mucosal Immunol. 2008:1(Suppl 1):S43-6.

91. Elias KM, Laurence A, Davidson TS, Stephens G, Kanno Y, Shevach EM, O'Shea JJ. Retinoic acid inhibits Th17 polarization and enhances FoxP3 expression through a Stat-3/Stat-5 independent signaling pathway. Blood. 2008;111:1013-20.

92. Zakrzewski JL, van den Brink MR, Hubbell JA. Overcoming immunological barriers in regenerative medicine. Nat Biotechnol. 2014;32:786-94.

93. Benichou G, Thomson AW. Direct versus indirect allorecognition pathways: on the right track. Am J Transplant. 2009;9:655-6.

94. Hoffmann P, Eder R, Kunz-Schughart LA, Andreesen R, Edinger M. Large-scale in vitro expansion of polyclonal human $\mathrm{CD} 4(+) C D 25$ high regulatory T cells. Blood. 2004;104:895-903.

95. Safinia N, Leech J, Hernandez-Fuentes M, Lechler R, Lombardi G. Promoting transplantation tolerance; adoptive regulatory $T$ cell therapy. Clin Exp Immunol. 2013;172:158-68.

96. Ohki H, Martin C, Corbel C, Coltey M, Le Douarin NM. Tolerance induced by thymic epithelial grafts in birds. Science. 1987;237:1032-5.

97. Salaun J, Bandeira A, Khazaal I, Calman F, Coltey M, Coutinho A, Le Douarin NM. Thymic epithelium tolerizes for histocompatibility antigens. Science. 1990;247:1471-4.

98. Modigliani Y, Coutinho A, Pereira P, Le Douarin N, Thomas-Vaslin V, Burlen-Defranoux O, Salaun J, Bandeira A. Establishment of tissuespecific tolerance is driven by regulatory $T$ cells selected by thymic epithelium. Eur J Immunol. 1996;26:1807-15.

99. Bigenzahn S, Blaha P, Koporc Z, Pree I, Selzer E, Bergmeister H, Wrba F, Heusser C, Wagner K, Muehlbacher F, Wekerle T. The role of non-deletional tolerance mechanisms in a murine model of mixed chimerism with costimulation blockade. Am J Transplant. 2005;5:1237-47.

100. Issa F, Schiopu A, Wood KJ. Role of T cells in graft rejection and transplantation tolerance. Expert Rev Clin Immunol. 2010;6:155-69.

101. Jiang X, Morita M, Sugioka A, Harada M, Kojo S, Wakao H, Watarai H, Ohkohchi N, Taniguchi M, Seino K. The importance of $\mathrm{CD}_{2} 5^{+} \mathrm{CD} 4^{+}$ regulatory $T$ cells in mouse hepatic allograft tolerance. Liver Transplant. 2006:12:1112-8

102. Pasquet L, Douet JY, Sparwasser T, Romagnoli P, van Meerwijk JP. Long-term prevention of chronic allograft rejection by regulatory T-cell immunotherapy involves host Foxp3-expressing T cells. Blood. 2013:121:4303-10.

103. Taylor PA, Lees CJ, Blazar BR. The infusion of ex vivo activated and expanded CD4(+)CD25(+) immune regulatory cells inhibits graftversus-host disease lethality. Blood. 2002;99:3493-9.

104. Brazio PS, Munivenkatappa RB, Bojovic B, Ha JS, Brown EN, Hess AS, Bartlett ST, Rodriguez ED, Barth RN. Regulatory T cells are not predictive of outcomes in a nonhuman primate model of vascularized composite allotransplantation. Transplantation. 2013;96:267-73.

105. Joffre O, Santolaria T, Calise D, AI Saati T, Hudrisier D, Romagnoli P, van Meerwijk JP. Prevention of acute and chronic allograft rejection with $\mathrm{CD}^{+}{ }^{+} \mathrm{CD} 25^{+} \mathrm{Foxp}^{+}$regulatory T lymphocytes. Nat Med. 2008;14:88-92.

106. Hoffmann P, Ermann J, Edinger M, Fathman CG, Strober S. Donor-type CD4(+)CD25(+) regulatory T cells suppress lethal acute graft-versushost disease after allogeneic bone marrow transplantation. J Exp Med. 2002;196:389-99.

107. Jiang S, Tsang J, Game DS, Stevenson S, Lombardi G, Lechler RI. Generation and expansion of human $\mathrm{CD} 4^{+} \mathrm{CD} 25^{+}$regulatory $T$ cells with indirect allospecificity: potential reagents to promote donor-specific transplantation tolerance. Transplantation. 2006;82:1738-43.

108. Golshayan D, Jiang S, Tsang J, Garin MI, Mottet C, Lechler RI. In vitroexpanded donor alloantigen-specific $\mathrm{CD} 4^{+} \mathrm{CD} 25^{+}$regulatory T cells promote experimental transplantation tolerance. Blood. 2007;109:827-35.

109. Karim M, Feng G, Wood KJ, Bushell AR. CD25 ${ }^{+} \mathrm{CD} 4^{+}$regulatory T cells generated by exposure to a model protein antigen prevent allograft rejection: antigen-specific reactivation in vivo is critical for bystander regulation. Blood. 2005;105:4871-7.

110. Moore C, Tejon G, Fuentes C, Hidalgo Y, Bono MR, Maldonado P, Fernandez R, Wood KJ, Fierro JA, Rosemblatt M, et al. Alloreactive regulatory T cells generated with retinoic acid prevent skin allograft rejection. Eur J Immunol. 2015;45:452-63.

111. Issa F, Hester J, Milward K, Wood KJ. Homing of regulatory T cells to human skin is important for the prevention of alloimmunemediated pathology in an in vivo cellular therapy model. PLOS ONE. 2012;7:e53331.

112. Kingsley $\mathrm{Cl}$, Karim M, Bushell $\mathrm{AR}$, Wood $\mathrm{KJ} . \mathrm{CD} 25^{+} \mathrm{CD} 4^{+}$regulatory ${ }^{\top}$ cells prevent graft rejection: CTLA-4- and IL-10-dependent immunoregulation of alloresponses. J Immunol. 2002;168:1080-6.

113. Tsang JY, Tanriver $Y$, Jiang $S$, Xue SA, Ratnasothy $K$, Chen D, Stauss HJ, Bucy RP, Lombardi G, Lechler R. Conferring indirect allospecificity on $\mathrm{CD}^{+}{ }^{+} \mathrm{CD} 25^{+}$Tregs by TCR gene transfer favors transplantation tolerance in mice. J Clin Invest. 2008;118:3619-28.

114. Benichou G, Tonsho M, Tocco G, Nadazdin O, Madsen JC. Innate immunity and resistance to tolerogenesis in allotransplantation. Front Immunol. 2012;3:73.

115. Nadazdin O, Boskovic S, Murakami T, Tocco G, Smith RN, Colvin RB, Sachs DH, Allan J, Madsen JC, Kawai T, et al. Host alloreactive memory T cells influence tolerance to kidney allografts in nonhuman primates. Sci Transl Med. 2011;3:86ra51.

116. Seneschal J, Clark RA, Gehad A, Baecher-Allan CM, Kupper TS. Human epidermal Langerhans cells maintain immune homeostasis in skin by activating skin resident regulatory $T$ cells. Immunity. 2012;36:873-84.

117. van der Aar AM, Picavet DI, Muller FJ, de Boer L, van Capel TM, Zaat SA, Bos JD, Janssen H, George TC, Kapsenberg ML, et al. Langerhans cells favor skin flora tolerance through limited presentation of bacterial antigens and induction of regulatory T cells. J Invest Dermatol. 2013:133:1240-9.

118. Kushwah $\mathrm{R}$, Hu J. Role of dendritic cells in the induction of regulatory $T$ cells. Cell Biosci. 2011;1:20.

119. Sanchez Rodriguez R, Pauli ML, Neuhaus IM, Yu SS, Arron ST, Harris HW, Yang SH, Anthony BA, Sverdrup FM, Krow-Lucal E, et al. Memory regulatory T cells reside in human skin. J Clin Invest. 2014;124:1027-36.

120. Rosenblum MD, Gratz IK, Paw JS, Lee K, Marshak-Rothstein A, Abbas AK. Response to self antigen imprints regulatory memory in tissues. Nature. 2011:480:538-42.

121. Ravishankar B, Shinde R, Liu H, Chaudhary K, Bradley J, Lemos HP, Chandler P, Tanaka M, Munn DH, Mellor AL, McGaha TL. Marginal zone CD169 ${ }^{+}$macrophages coordinate apoptotic cell-driven cellular recruitment and tolerance. Proc Natl Acad Sci USA. 2014;111:4215-20.

122. Thornley TB, Fang Z, Balasubramanian S, Larocca RA, Gong W, Gupta S, Csizmadia E, Degauque N, Kim BS, Koulmanda M, et al. Fragile TIM-4-expressing tissue resident macrophages are migratory and immunoregulatory. J Clin Invest. 2014;124:3443-54.

123. Lu LF, Lind EF, Gondek DC, Bennett KA, Gleeson MW, Pino-Lagos K, Scott ZA, Coyle AJ, Reed JL, Van Snick J, et al. Mast cells are essential intermediaries in regulatory T-cell tolerance. Nature. 2006;442:997-1002. 
124. Piconese S, Gri G, Tripodo C, Musio S, Gorzanelli A, Frossi B, Pedotti R, Pucillo CE, Colombo MP. Mast cells counteract regulatory T-cell suppression through interleukin-6 and OX40/OX40L axis toward Th17-cell differentiation. Blood. 2009;1 14:2639-48.

125. Tordesillas L, Mondoulet L, Blazquez AB, Benhamou PH, Sampson HA, Berin MC. Epicutaneous immunotherapy induces gastrointestinal $\mathrm{LAP}+$ regulatory $T$ cells and prevents food-induced anaphylaxis. J Allergy Clin Immunol. 2017;139(189-201):e184.

126. Schatton T, Yang J, Kleffel S, Uehara M, Barthel SR, Schlapbach C, Zhan Q, Dudeney S, Mueller H, Lee N, et al. ABCB5 Identifies Immunoregulatory Dermal Cells. Cell Rep. 2015;12:1564-74.

127. Clark RA, Kupper TS. IL-15 and dermal fibroblasts induce proliferation of natural regulatory $T$ cells isolated from human skin. Blood. 2007;109:194-202.

128. Pfisterer K, Lipnik KM, Hofer E, Elbe-Burger A. CD90(+) human dermal stromal cells are potent inducers of FoxP3(+) regulatory T cells. J Invest Dermatol. 2015;135:130-41.

129. Bobr A, Olvera-Gomez I, Igyarto BZ, Haley KM, Hogquist KA, Kaplan DH. Acute ablation of Langerhans cells enhances skin immune responses. J Immunol. 2010;185:4724-8.

130. Igyarto BZ, Kaplan DH. The evolving function of Langerhans cells in adaptive skin immunity. Immunol Cell Biol. 2010;88:361-5.

131. Eun SC, Baek RM, Park CG. Prolongation of the rat composite tissue allograft survival by the combination of tolerogenic immature dendritic cells and short-term treatment with FK506. Transplant Proc. 2013:45:1792-6.

132. Jukes JP, Wood KJ, Jones ND. Natural killer T cells: a bridge to tolerance or a pathway to rejection? Transplantation. 2007;84:679-81.

133. Gober MD, Fishelevich R, Zhao Y, Unutmaz D, Gaspari AA. Human natural killer T cells infiltrate into the skin at elicitation sites of allergic contact dermatitis. J Invest Dermatol. 2008;128:1460-9.

134. Tard C, Rouxel O, Lehuen A. Regulatory role of natural killer T cells in diabetes. Biomed J. 2015:38:484-95.

135. Hongo D, Tang X, Dutt S, Nador RG, Strober S. Interactions between NKT cells and Tregs are required for tolerance to combined bone marrow and organ transplants. Blood. 2012;119:1581-9.

136. Palathumpat V, Dejbakhsh-Jones S, Holm B, Strober S. Different subsets of $T$ cells in the adult mouse bone marrow and spleen induce or suppress acute graft-versus-host disease. J Immunol. 1992;149:808-17.

137. Pillai AB, George TI, Dutt S, Strober S. Host natural killer T cells induce an interleukin-4-dependent expansion of donor $\mathrm{CD}_{4}^{+} \mathrm{CD} 25^{+} \mathrm{Foxp} 3^{+} \mathrm{T}$ regulatory cells that protects against graft-versus-host disease. Blood. 2009;113:4458-67.

138. Brillard E, Pallandre JR, Chalmers D, Ryffel B, Radlovic A, Seilles E, Rohrlich PS, Pivot X, Tiberghien P, Saas P, Borg C. Natural killer cells prevent CD28-mediated Foxp3 transcription in $\mathrm{CD} 4{ }^{+} \mathrm{CD} 25^{-}$T lymphocytes. Exp Hematol. 2007;35:416-25.

139. Roy S, Barnes PF, Garg A, Wu S, Cosman D, Vankayalapati R. NK cells lyse T regulatory cells that expand in response to an intracellular pathogen. J Immunol. 2008;180:1729-36.

140. Hutchinson JA, Riquelme P, Sawitzki B, Tomiuk S, Miqueu P, Zuhayra M, Oberg HH, Pascher A, Lutzen U, Janssen U, et al. Cutting edge: immunological consequences and trafficking of human regulatory macrophages administered to renal transplant recipients. J Immunol. 2011:187:2072-8.

141. Raker VK, Domogalla MP, Steinbrink K. Tolerogenic dendritic cells for regulatory $T$ cell induction in man. Front Immunol. 2015;6:569.

142. Sagoo P, Perucha E, Sawitzki B, Tomiuk S, Stephens DA, Miqueu P, Chapman S, Craciun L, Sergeant R, Brouard S, et al. Development of a cross-platform biomarker signature to detect renal transplant tolerance in humans. J Clin Invest. 2010;120:1848-61.

143. Mauri C, Bosma A. Immune regulatory function of B cells. Annu Rev Immunol. 2012;30:221-41.

144. Shah S, Qiao L. Resting B cells expand a CD4 $4^{+} \mathrm{CD} 25^{+} \mathrm{Foxp}^{+}$Treg population via TGF-beta3. Eur J Immunol. 2008;38:2488-98.

145. Putnam AL, Safinia N, Medvec A, Laszkowska M, Wray M, Mintz MA, Trotta E, Szot GL, Liu W, Lares A, et al. Clinical grade manufacturing of human alloantigen-reactive regulatory $T$ cells for use in transplantation. Am J Transplant. 2013;13:3010-20.

146. Chandraker A, Arscott R, Murphy GF, Lian CG, Bueno EM, Marty FM, Rennke HG, Milford E, Tullius SG, Pomahac B. The management of antibody-mediated rejection in the first presensitized recipient of a fullface allotransplant. Am J Transplant. 2014;14:1446-52.

147. Morelon E, Petruzzo P, Kanitakis J, Dakpe S, Thaunat O, Dubois V, Choukroun G, Testelin S, Dubernard JM, Badet L, Devauchelle B. Face transplantation: partial graft loss of the first case 10 years later. Am J Transplant. 2017;17:1935-40.

148. Tang Q, Bluestone JA. Regulatory T-cell therapy in transplantation: moving to the clinic. Cold Spring Harb Perspect Med. 2013;3:a015552.

149. Furtado GC, de Lafaille MA, Kutchukhidze N, Lafaille JJ. Interleukin 2 signaling is required for CD4(+) regulatory T cell function. J Exp Med. 2002;196:851-7.

150. Zeiser R, Nguyen VH, Beilhack A, Buess M, Schulz S, Baker J, Contag CH, Negrin RS. Inhibition of $\mathrm{CD} 4{ }^{+} \mathrm{CD} 25^{+}$regulatory T-cell function by calcineurin-dependent interleukin-2 production. Blood. 2006;108:390-9.

151. Hartemann A, Bensimon G, Payan CA, Jacqueminet S, Bourron O, Nicolas N, Fonfrede M, Rosenzwajg M, Bernard C, Klatzmann D. Low-dose interleukin 2 in patients with type 1 diabetes: a phase 1/2 randomised, double-blind, placebo-controlled trial. Lancet Diabetes Endocrinol. 2013;1:295-305.

152. Arroyo Hornero R, Betts GJ, Sawitzki B, Vogt K, Harden PN, Wood KJ. CD45RA distinguishes $\mathrm{CD} 4^{+} \mathrm{CD} 25^{+} \mathrm{CD} 127^{-} /$low TSDR demethylated regulatory $T$ cell subpopulations with differential stability and susceptibility to tacrolimus-mediated inhibition of suppression. Transplantation. 2017;101:302-9.

153. Battaglia M, Stabilini A, Draghici E, Gregori S, Mocchetti C, Bonifacio E, Roncarolo MG. Rapamycin and interleukin-10 treatment induces $T$ regulatory type 1 cells that mediate antigen-specific transplantation tolerance. Diabetes. 2006;55:40-9.

154. Delgoffe GM, Kole TP, Zheng Y, Zarek PE, Matthews KL, Xiao B, Worley PF, Kozma SC, Powell JD. The mTOR kinase differentially regulates effector and regulatory T cell lineage commitment. Immunity. 2009;30:832-44.

155. Raimondi G, Sumpter TL, Matta BM, Pillai M, Corbitt N, Vodovotz Y, Wang Z, Thomson AW. Mammalian target of rapamycin inhibition and alloantigen-specific regulatory $T$ cells synergize to promote long-term graft survival in immunocompetent recipients. J Immunol. 2010;184:624-36.

156. Riley JL, June CH, Blazar BR. Human T regulatory cell therapy: take a billion or so and call me in the morning. Immunity. 2009;30:656-65.

157. Brunstein CG, Miller JS, McKenna DH, Hippen KL, DeFor TE, Sumstad D, Curtsinger J, Verneris MR, MacMillan ML, Levine BL, et al. Umbilical cord blood-derived T regulatory cells to prevent GVHD: kinetics, toxicity profile, and clinical effect. Blood. 2016;127:1044-51.

158. Godfrey WR, Spoden DJ, Ge YG, Baker SR, Liu B, Levine BL, June CH, Blazar BR, Porter SB. Cord blood CD4(+)CD25(+)-derived T regulatory cell lines express FoxP3 protein and manifest potent suppressor function. Blood. 2005;105:750-8.

159. Tang Q, Lee K. Regulatory T-cell therapy for transplantation: how many cells do we need? Curr Opin Organ Transplant. 2012;17:349-54.

160. Jeffery HC, Braitch MK, Brown S, Oo YH. Clinical potential of regulatory $T$ cell therapy in liver diseases: an overview and current perspectives. Front Immunol. 2016;7:334.

161. Hoffmann P, Eder R, Edinger M. Polyclonal expansion of human CD4(+) CD25(+) regulatory T cells. Methods Mol Biol. 2011;677:15-30.

162. Hippen KL, Merkel SC, Schirm DK, Nelson C, Tennis NC, Riley JL, June $\mathrm{CH}$, Miller JS, Wagner JE, Blazar BR. Generation and large-scale expansion of human inducible regulatory $T$ cells that suppress graft-versushost disease. Am J Transplant. 2011;11:1148-57.

163. Safinia N, Scotta C, Vaikunthanathan T, Lechler RI, Lombardi G. Regulatory T Cells: serious contenders in the promise for immunological tolerance in transplantation. Front Immunol. 2015;6:438.

164. Sagoo P, Ali N, Garg G, Nestle FO, Lechler RI, Lombardi G. Human regulatory $T$ cells with alloantigen specificity are more potent inhibitors of alloimmune skin graft damage than polyclonal regulatory T cells. Sci Transl Med. 2011;3:83ra42.

165. Landwehr-Kenzel S, Issa F, Luu SH, Schmuck M, Lei H, Zobel A, Thiel A Babel N, Wood K, Volk HD, Reinke P. Novel GMP-compatible protocol employing an allogeneic B cell bank for clonal expansion of allospecific natural regulatory T cells. Am J Transplant. 2014;14:594-606.

166. MacDonald KG, Hoeppli RE, Huang Q, Gillies J, Luciani DS, Orban PC Broady R, Levings MK. Alloantigen-specific regulatory T cells generated with a chimeric antigen receptor. J Clin Invest. 2016;126:1413-24. 
167. Fransson M, Piras E, Burman J, Nilsson B, Essand M, Lu B, Harris RA, Magnusson PU, Brittebo E, Loskog AS. CAR/FoxP3-engineered T regulatory cells target the CNS and suppress EAE upon intranasal delivery. J Neuroinflammation. 2012;9:112.

168. Blat D, Zigmond E, Alteber Z, Waks T, Eshhar Z. Suppression of murine colitis and its associated cancer by carcinoembryonic antigen-specific regulatory T cells. Mol Ther. 2014;22:1018-28.

169. Yoon J, Schmidt A, Zhang AH, Konigs C, Kim YC, Scott DW. FVIII-specific human chimeric antigen receptor T-regulatory cells suppress T- and B-cell responses to FVIII. Blood. 2017;129:238-45.
170. Berdien B, Mock U, Atanackovic D, Fehse B. TALEN-mediated editing of endogenous T-cell receptors facilitates efficient reprogramming of $\mathrm{T}$ lymphocytes by lentiviral gene transfer. Gene Ther. 2014;21:539-48.

171. Bluestone JA, Buckner JH, Fitch M, Gitelman SE, Gupta S, Hellerstein MK, Herold KC, Lares A, Lee MR, Li K, et al. Type 1 diabetes immunotherapy using polyclonal regulatory T cells. Sci Transl Med. 2015;7:315ra189.

\section{Submit your next manuscript to BioMed Central and we will help you at every step:}

- We accept pre-submission inquiries

- Our selector tool helps you to find the most relevant journal

- We provide round the clock customer support

- Convenient online submission

- Thorough peer review

- Inclusion in PubMed and all major indexing services

- Maximum visibility for your research

Submit your manuscript at

www.biomedcentral com/submit 